Sección Control / Control

Artículos de investigación / Research paper

\title{
Impact of a synthetic insecticide and plant extracts on Aphis craccivora (Hemiptera: Aphididae) and coccinellid species in common beans
}

\author{
Impacto de un insecticida sintético y extractos de plantas en Aphis craccivora \\ (Hemiptera: Aphididae) y especies de coccinélidos en frijoles comunes
(iD MATEUS CARDOSO DE SOUSA ${ }^{1}$, iD VANESA ANDALÓ ${ }^{1 *}$, iD RENAN ZAMPIROLI ${ }^{1}$, (iD CLEYTON BATISTA DE ALVARENGA ${ }^{1}$, ID GLEICE APARECIDA DE ASSIS ${ }^{1}$, iD FÁBIO JANONI CARVALHO $^{2}$, iD WELINGTON ADOLFO DE BRITO ${ }^{1}$, iD LUCAS SILVA DE FARIA ${ }^{1}$

\begin{abstract}
${ }^{1}$ Federal University of Uberlândia (UFU), Monte Carmelo, Brasil, mateus_sousa_cardoso@hotmail.com, vanessaandalo@ufu.br, renanzampiroli@ufu.br, cleytonalvarenga@ufu.br, gleice@ufu.br, wabto@hotmail.com, lucassilvafaria@hotmail.com² Federal Institute of Triângulo Mineiro, Uberaba, Brasil fjcarvalho1@gmail.com
\end{abstract}

\begin{abstract}
*Corresponding author
Vanesa Andaló, 'Federal University of Uberlândia (UFU), km 1, LMG-746, Monte Carmelo - MG, Brasil vanessaandalo@ufu.br, https:// orcid.org/0000-0002-6310-1680

Suggested citation

SOUSA M. C.; ANDALO V; ZAMPIROLI R.; ALVARENGA C. B.; ASISS G. A.; CARVALHO F. J.; BRITO W. A.; FARIA L. S. 2021. Impact of a synthetic insecticide and plant extracts on Aphis craccivora (Hemiptera: Aphididae) and coccinellid species in common beans. Revista Colombiana de Entomología 47 (2): e10992. https://doi.org/10.25100/socolen. v47i2.10992
\end{abstract}

Received: Feb-08-2021

Accepted: Oct-04-2021

Published: Dic-03-2021

Revista Colombiana de Entomología ISSN (Print): 0120-0488

ISSN (On Line): 2665-4385

https://revistacolombianaentomologia.univalle.edu.co

Open access

(c) (1) (2) (2) BY-NC-SA 4.0

Publishers: Sociedad Colombiana de Entomología SOCOLEN (Bogotá, D. C., Colombia) https://www.socolen.org.co

Universidad del Valle (Cali, Colombia)

https://www.univalle.edu.co

(C) 2021 Sociedad Colombiana de Entomología SOCOLEN y Universidad del Valle - Univalle
Abstract: Bean crop is attacked by several phytophagous insects, affecting its production and causing losses to farmers. Among the insects considered as bean crop pests, aphids can cause economic damage by continuously sucking the plant sap throughout crop development. Thus, this study aimed to evaluate the control of Aphis craccivora on bean crop with insecticides and its effect on the presence of ladybugs. The tested products were: 1) imidacloprid + bifenthrin; 2) neem extract; 3) d-limonene, and, as a control treatment, water was applied. Insect mortality and the presence of ladybugs were checked every three days until harvest. There was a reduction in the population of aphids after the application of the products for up to 27 days. The presence of ladybugs was higher in the control treatment than in the treatments with insecticides. Thus, the tested products were considered potential in the control of $A$. craccivora. However, they also negatively affected the presence of coccinellids.

Keywords: Aphid, biological control, chemical control, Phaseolus vulgaris, spraying.

Resumen: El cultivo del frijol es atacado por varios insectos fitófagos, lo que afecta su producción y causa pérdidas a los agricultores. Entre los insectos considerados plagas de los cultivos, los pulgones pueden causar daños económicos al succionar continuamente la savia de la planta durante el desarrollo del cultivo. El objetivo de este estudio fue evaluar el control del pulgón Aphis craccivora en cultivo de frijol con insecticidas, así como su influencia en la presencia de coccinélidos. Los productos probados están formulados a base de: 1) imidacloprid + bifentrina; 2) extracto de neem; 3) d-limoneno, y como control se aplicó agua. Se registró la mortalidad de insectos y la presencia de coccinélidos cada tres días hasta la cosecha. En cuanto a la mortalidad de pulgones, hubo una reducción en la población de insectos después de la aplicación de los productos hasta los 27 días. La presencia de coccinélidos fue mayor en el tratamiento control que en los tratamientos con insecticidas. Por lo tanto, los productos probados se consideraron potenciales en el control de A. craccivora, sin embargo, afectaron la presencia de coccinélidos.

Palabras clave: Áfido, control biológico, control químico, Phaseolus vulgari, pulverización.

\section{Introduction}

The common bean, Phaseolus vulgaris L. (Fabaceae) is one of the main crops produced in Brazil and the world due to the extensive planting areas and high consumer market. It is one of the agricultural products of greatest economic and social importance, with a national production of 3,022.5 tons harvested in the 2018/2019 harvest in 2,927.3 hectares (Conab 2020).

Among the insects considered to be crop pests, the black aphid, Aphis craccivora Koch (Hemiptera: Aphididae), can cause direct damage by feeding on the plant sap and causing indirect damage by the presence of its honeydew or by transmitting viruses, that cause leaf shrinkage and reduced growth (Obopile 2006).

According to Abdou et al. (2012), the economic threshold of A. craccivora to broad bean (Vicia faba L.) is 8.6 aphids per plant, making it necessary to control it before the insect population reaches this threshold. They are insects that have an aggregated distribution model, occurring in foci or bands, and can reach high 
population densities, causing economic losses in common bean crops (Silva et al. 2014).

The biological control of aphids is performed by natural enemies such as ladybugs (Coleoptera: Coccinellidae), with a high potential for aphid (Hemiptera: Aphididae) predation (Iperti 1999). According to Pervez et al. (2019), female ladybugs of Hippodamia variegata (Goeze) may be considered as an effective biocontrol agent of $A$. craccivora and their predation potential is associated with increases in prey density.

In order to reduce the population of $A$. craccivora plant extracts can be used in the control of pest insects, such as neem oil, which is obtained from the plant Azadirachta indica A. Juss. (Meliaceae). Among the effects of azadirachtin on aphids, ecdysis inhibition can be highlighted, reducing ecdysonium concentration in the hemolymph (Gonçalves and Bleicher 2006).

D-limonene, which extract is obtained from Citrus spp. plants, is also considered a potential substance to control insects since it can cause stimulation of the motor system resulting in rapid body paralysis, leading to the death of the insect (Khani and Asghari 2012).

The proper application and selection of phytosanitary products is a key to obtain effective treatments. The proper application may be measured using different variables that help to infer their efficiency. The volumetric median diameter (VMD) stands out, as well as Dv0.1, Dv0.9, percentage of coverage, droplet density, relative amplitude, and others. Studies conducted by Cunha et al. (2019) and Sasaki et al. (2016) reinforce the importance of these parameters. The application efficiency evaluation variables are obtained by an artificial target, positioned next to the plant leaves, aiming to simulate the deposit of the drops; it is a useful and accessible tool for service providers, producers and researchers (Alvarenga et al. 2014).

Among the products registered for common bean crop, only neonicotinoids are available for the chemical control of aphids (Agrofit 2020). These insecticides can affect populations of pollinating insects, making it necessary to search for control alternatives, such as insecticides with different active ingredients or biological control using predators, parasitoids, and entomopathogens (Morais et al. 2018).

Thus, this study aimed to evaluate the control of $A$. craccivora in bean crops, using chemical insecticides, plant extracts, and coccinellids, and test the application efficiency of chemical and botanical insecticides.

\section{Material and methods}

Experiment establishment. The experiment was carried out under arch-greenhouse conditions, with dimensions of $7 \times 21$ $\mathrm{m}$ and a 4-m high ceiling, covered with transparent 150-micron polyethylene film, additive against ultraviolet rays, and side curtains of white anti-aphid screen. Common bean seeds from the commercial group Pérola Carioca were sown in plastic pots $(12 \mathrm{~L})$ filled with $10 \mathrm{~kg}$ of RED LATOSOL of clay texture. Seedling emergence occurred six days after sowing when thinning was carried out, leaving one to two plants per pot.

Lime was applied to correct the soil $\mathrm{pH}$. The soil was fertilized following the fertilization recommendation for the bean crop, according to Ribeiro et al. (1999), at the respective dosages $2.5 \mathrm{~g}$ of urea $\left(\mathrm{CO}\left(\mathrm{NH}_{2}\right)_{2}\right)(45 \% \mathrm{~N}), 1.0 \mathrm{~g}$ of potassium chloride $\left(\mathrm{KCl}\left(60 \% \mathrm{~K}_{2} \mathrm{O}\right)\right)$, and $19 \mathrm{~g}$ of simple superphos- phate $\left(\mathrm{Ca}\left(\mathrm{H}_{2} \mathrm{PO}_{4}\right) 2 . \mathrm{H}_{2} \mathrm{O}+\mathrm{CaSO}_{4} \cdot 2 \mathrm{H}_{2} \mathrm{O}\left(18 \% \mathrm{P}_{2} \mathrm{O}_{5}, 20 \% \mathrm{Ca}\right.\right.$, $10 \% \mathrm{~S}$ ) at sowing. Twenty and 30 days after emergence, 3.5 $\mathrm{g}$ of urea was applied as topdressing fertilization, and thinning was performed. Foliar fertilization was carried out with $0.4 \mathrm{~g} \mathrm{~L}^{-1}$ molybdenum $(\mathrm{Mo}=14 \%, \mathrm{Co}=1.5 \%)$ at 25 days after sowing, besides manual removal of weeds throughout the crop cycle.

The experiment was set in a completely randomized design, consisting of three treatments besides the control treatment. Three phytosanitary products were tested: 1) commercial product Galil ${ }^{\circledR}$ based on imidacloprid + bifenthrin at $1.75 \mathrm{~mL} \mathrm{~L}^{-1}$ (neonicotinoid and pyrethroid, respectively); 2) non-commercial product formulated based on neem extract, at a concentration of $35 \%$; and 3 ) non-commercial product based on d-limonene, at a concentration of $10 \%$, both at a dose of $10 \mathrm{~mL} \mathrm{~L}^{-1}$. In the control treatment, only water was sprayed.

Each treatment consisted of seven replications, each containing five pots; in each pot, there were from one to three plants, totaling 35 pots per treatment and 140 pots in the experiment. The pots were arranged so that one of them was located in the central part, with the other four placed around it. The spacing among the treatments in the greenhouse was $1.5 \mathrm{~m}$, and the spacing among replications was $1.0 \mathrm{~m}$. Each pot was irrigated daily with approximately $1.0 \mathrm{~L}$ of water.

The artificial aphid infestation was carried out 30 days after seedling emergence. Each plant was infested with two aphid colonies, composed of about one female and four to six nymphs in each colony. After a week of the introduction of aphids, a couple of each predatory ladybug species Cycloneda sanguinea (L.), Eriopis conexa (German), Harmonia axyridis (Pallas), and Hippodamia convergens Guérin-Méneville (Coleoptera: Coccinellidae) were released per replication, totaling about 28 couples per treatment.

The products were applied 40 days after emergence. The application was made at the V5 stage, using an ATR 5.0 albuz spray tip (green), with an empty conical jet, opening angle of $80^{\circ}$, working pressure of $500 \mathrm{kPa}$ (Evreux Cedex, France). The average temperature during the application varied between 24 and $30^{\circ} \mathrm{C}$ and the relative humidity, from 36 to $58 \%$, respectively. The spray volume was calculated considering the recommendation of $200 \mathrm{~L} \mathrm{ha}^{-1}$, and it was applied using a constant pressure sprayer.

Experiment evaluation. The application parameters were evaluated using water-sensitive papers positioned in the lower part of the plants, in the central plant of the plot. Subsequently, they were analyzed using the DropScan ${ }^{\circledR}$ software (developed by Leon Sistemas Digitais, 2019). The evaluations were carried out to verify droplet density parameters, percentage of coverage, and relative amplitude. The data were subjected to analysis of variance and the F-test at 5\% probability with the aid of the statistical software ASSISTAT (Silva and Azevedo 2009).

To check population indices, evaluations were carried out every three days, for 36 days, counting the number of aphids present on two leaves (located in the top) per plant of the central pot (from which the average number of aphids per plant was calculated) and the total number of ladybugs in the whole plant was counted. The evaluation was not destructive; the data were collected only by observing the presence of aphids and ladybugs. The data were subjected to analysis of variance 
and the Tukey test at $5 \%$ probability to compare the action of phytosanitary products on aphids and ladybugs. To assess the fluctuation of the aphids' population over time, regression analysis was performed.

At the end of the bean cycle, 90 days after sowing (DAS), manual harvesting was carried out, where each treatment with its respective replications were properly identified and stored in linen bags for the following evaluations: pods per replication, pods per plant, seeds per pod, total seed mass. The data obtained were subjected to the F test at 5\% probability with the statistical software ASSISTAT (Silva and Azevedo 2009).

\section{Results and discussion}

Droplet density, percentage of coverage, and relative amplitude of the droplet spectrum were not affected by the type of product applied; that is, there was no interaction between products and spray nozzle, however, this has been considered a common interaction in phytosanitary treatments. Different factors such as water quality, $\mathrm{pH}$ of the solution, physicochemical properties of the suspension, could influence in this interaction, however, these factors were not evaluated in separate in the present study (Alvarenga et al. 2018). The ATR nozzle showed a good droplet penetration, even in the lower part of the plant, indicating a good choice for aphid control. Therefore, the effects on control effectiveness can be attributed to the different phytosanitary products applied and not to the application technology used (Table 1).

Table 1. Parameters to characterize the droplet spectrum of products with insecticidal action to control Aphis craccivora in Phaseolus vulgaris in a greenhouse.

\begin{tabular}{lccc}
\hline \multicolumn{1}{c}{ Treatment } & $\begin{array}{c}\text { Density } \\
\left.\text { (drop cm }^{\mathbf{2}}\right)^{*}\end{array}$ & $\begin{array}{c}\text { Coverage } \\
\mathbf{( \% )}^{*}\end{array}$ & $\begin{array}{c}\text { Relative } \\
\text { amplitude }^{*}\end{array}$ \\
\hline Control & 38.2 & 83.5 & 0.96 \\
\hline Imidacloprid + bifenthrin & 81.1 & 66.6 & 1.03 \\
\hline Neem extract & 55.2 & 74.7 & 1.20 \\
\hline d-limonene & 81.1 & 59.4 & 1.80 \\
\hline
\end{tabular}

"Data not significant according to the $\mathrm{F}$ test at $5 \%$ probability.

When assessing aphid mortality, a reduction in insect population in all treatments was observed after applying the products. Also, the products caused a high control, considering that, in some evaluations, no aphids were found on the leaves, indicating that the population was almost zero (Fig. 1).

Abdou et al. (2012) established an economic injury level (EIL) of 8.6 aphids per plant for V. faba. In this study, carried out on $P$. vulgaris plants, this value was reached only in the control and after the end of the residual effect of the products (Figs. 1 and 2). The different levels of aphids' population could be associated to their behavior feeding in distinct species of plants, and also due to the different conditions (biotic and abiotic) under which the studies were conducted.

It was found that there was a gradual increase in aphid population over time. The aphid population followed a sigmoidal distribution for the treatments imidacloprid + bifenthrin $\left(\mathrm{R}^{2}=94.45 \%\right)$ and d-limonene $\left(\mathrm{R}^{2}=93.74 \%\right)$. For imidacloprid + bifenthrin, the first aphid was estimated after the $24^{\text {th }}$ day. Then, the population increased exponentially to 40 aphids per plant on the $31^{\text {st }}$ day. After that, the aphid population was stabilized. For the d-limonene treatment, the first aphid appeared on the $27^{\text {th }}$ day. However, the population increased exponentially up to 47 aphids, and then the population stabilized at this peak.

The population density followed an exponential model $\left(\mathrm{R}^{2}=91.14 \%\right)$ where the control was efficient for 13 days in the treatment with neem extract. After the $13^{\text {th }}$ day, the first aphid was estimated, and after the $25^{\text {th }}$ day, the total number of aphids was estimated at 10 individuals per plant. After that, the aphid population expanded exponentially, where the highest population density was found on the last day of the evaluation and estimated at 76 aphids (Fig 1).

The estimated equations suggested that the three treatments were efficient to control the aphid population for at least 13 days. Imidacloprid + bifenthrin and d-limonene were more efficient than neem extract controlling the aphids for at least 24 days, and even with the aphid population growth, the population reached a peak and stopped at odds to neem extract, where the population kept growing, suggesting a possible residual effect in the plant. The residual effect of the non-commercial products was lower than the commercial product, so the interval of application should be also shorter, to avoid the increase of the aphid population and cause economic damage.

Das et al. (2008) found that neem extract caused mortality between 80 and $89 \%$ of $A$. craccivora aphids, but the authors pointed out that mortality occurred mainly soon after the application of the product; after 3 or 4 weeks, the population of aphids grew again, which could occur due to the end of the residual effect of the product.

In the control treatment, both aphids and coccinellids were present throughout the evaluations (Fig. 2), whereas in the other treatments, there was a reduction in the population of these insects (Table 2). The population had a quadratic behavior starting with 40 aphids per plant, decreasing to 11 aphids on the $10^{\text {th }}$ day, and reaching 191 aphids per plant on the last day of evaluation. The coccinellids' population increased exponentially with the presence of the aphids on the plant, appearing on the $25^{\text {th }}$ day and reaching a population of 13 coccinellids on the last day of evaluation. The coccinellids' population for the other treatments was not significant, with fewer observations with the presence of this natural enemy.

Considering the mean incidence of the pest insect over the evaluated period (36 days after application), there were no differences between the tested products. Still, they differed from the control (Table 2), reducing the aphid population. It is possible to infer the action potential of the products as an alternative in the control of $A$. craccivora.

Ofuya (1997) observed that the extracts of Zingiber officinale Roscoe and Aframomum melegueta K. Schum., despite their insecticidal effect on aphids, also cause harmful effects to coccinellids that are predatory to A. craccivora.

Ofuya $(1995,1997)$ found that Cheilomenes lunata (Fabricius) and Cheilomenes vicina (Mulsant) (Coleoptera: Coccinellidae) have potential in the control of A. craccivora in cowpea. However, the author observed that, with the decline in the aphid population, there was also a reduction in the coccinellids population, which may be related to the lesser ability of these species to exploit unstable food resources. The decline of coccinellids was also observed in the present study which may reflect the population of the natural enemy following the population level of the prey. 

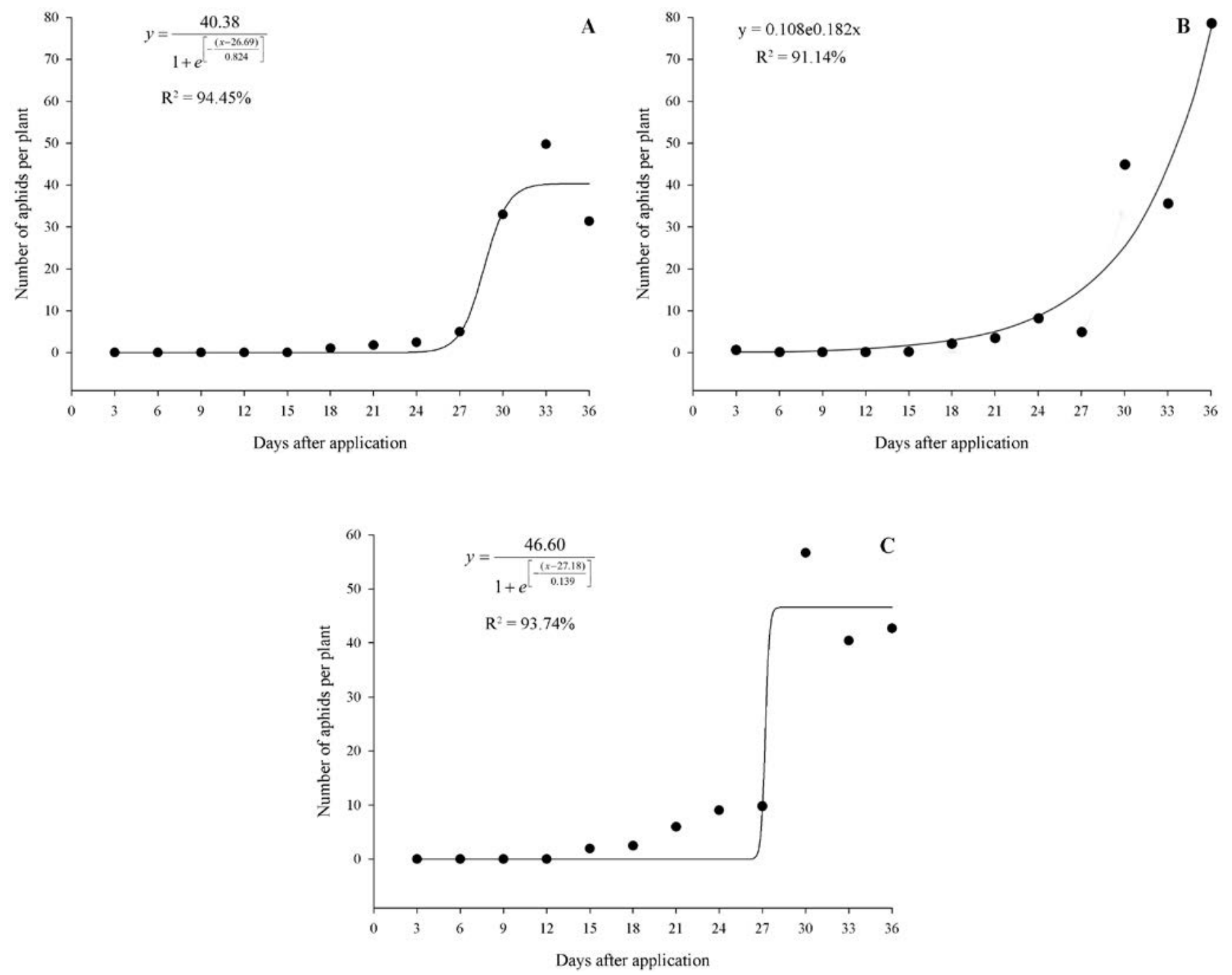

\begin{tabular}{lccc}
\hline \multicolumn{1}{c}{ Treatment } & Equation & Model & $\mathbf{R}^{2}$ \\
\hline Imidacloprid + bifenthrin & $y=\frac{40.38}{1+e^{\left[-\frac{(x-26.69)}{0.824}\right]}}$ & Sigmoidal & $94.45 \%$ \\
\hline Neem extract & $y=0.108 \times e^{0.182 x}$ & Exponential & $91.14 \%$ \\
\hline d-limonene & $y=\frac{46.60}{1+e^{\left[-\frac{(x-27.18)}{0.139}\right]}}$ & Sigmoidal & $93.74 \%$ \\
\hline
\end{tabular}

Figure 1. Aphid population fluctuation. A. imidacloprid + bifenthrin. B. Neem extract. C. d-limonene. 


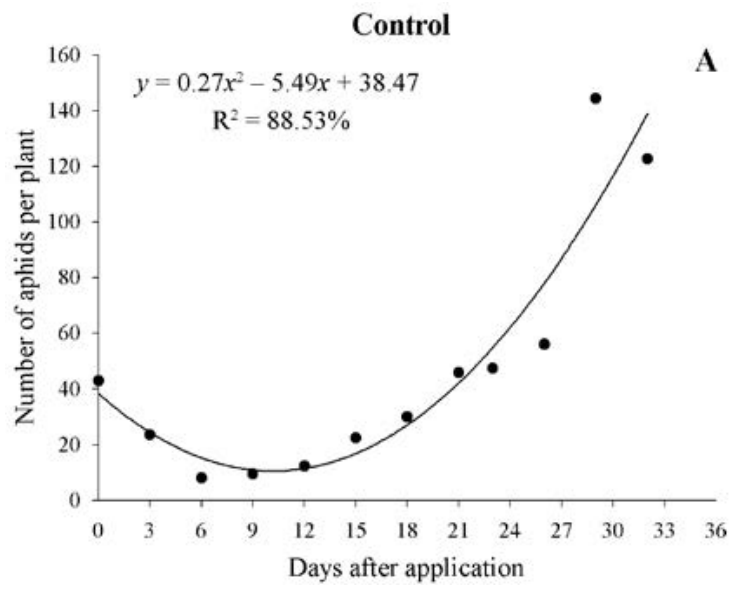

Figure 2. Population fluctuation of Aphis craccivora (A) and coccinellids (B) in the control treatment.
Table 2. Mean incidence of Aphis craccivora along 36 days of evaluation in the bean crop using different products.

\begin{tabular}{lc}
\hline \multicolumn{1}{c}{ Treatment } & Number of aphids $( \pm$ SD) \\
\hline Neem extract & $6.47 \pm 1.99 \mathrm{a}$ \\
\hline d-limonene & $7.52 \pm 2.21 \mathrm{a}$ \\
\hline imidacloprid + bifenthrin & $4.20 \pm 1.32 \mathrm{a}$ \\
\hline Control & $33.58 \pm 6.48 \mathrm{~b}$ \\
\hline
\end{tabular}

*Means \pm standard deviation (SD) followed by the same letter did not differ by the Tukey's test $(\mathrm{p}<0.05)$.

Although products based on neem and d-limonene are not registered by the Ministry of Agriculture, Livestock, and Supply (Agrofit 2020), they were as effective as the insecticide imidacloprid + bifenthrin, highlighting the potential for use in the control of $A$. craccivora (Table 2 ).

The product based on imidacloprid + bifenthrin is registered for the control of aphids in cotton, melon, and wheat, and also for beans for the control of whitefly, Bemisia tabaci (Gennadius) (Hemiptera: Aleyrodidae), and cucurbit beetle, Diabrotica speciosa (Germar) (Coleoptera: Chrysomelidae) (Agrofit 2020). Thus, as the product proved to be effective in controlling aphids, its use can provide the control of a greater number of targets in an application.

Several studies have been conducted to verify the effect of plant extracts on the control of $A$. craccivora. Rabelo and Bleicher (2014) found that extracts of atemoya seeds, Annona cherimola Mill. x Annona squamosa L., and soursop, $A$. squamosa (Annonaceae), effectively reduce the population of A. craccivora in cowpea, Vigna unguiculata (L.) Walp., causing mortality of about $98 \%$ in aphid populations.
Torkey et al. (2009) observed that the extract of Citrullus colocynthis (L.) Schrad. has an insecticidal effect on $A$. craccivora, which occurs, according to Yaniv et al. (1999), due to the presence of ingredients such as saponins, alkaloids, and glycosides. Ofuya and Okuku (1994) found that the extracts of $Z$. officinale and Cymbopogon citratus (DC) Stapf inhibit the reproduction and increase the mortality of aphid nymphs.

According to Santos et al. (2011), the use of plant extracts has the potential to control $A$. craccivora; the extracts of ginger and cloves, for example, caused mortality above $70 \%$ and can be used both for obtaining natural insecticides and for the isolation of active ingredients to synthesize new phytosanitary products. Promising results were also obtained in this study when products formulated with d-limonene and neem extract were used since there was a reduction in the aphid population equivalent to that caused by the chemical insecticides.

Obopile and Ositile (2010) justify that the various tests with plant extracts are carried out to seek an alternative to chemical control due to the greater concern with the environment and the health of producers and consumers; also, the use of products formulated with plant extracts can reduce costs in pest control. Plant extracts may also be used as sources of compounds to synthesize new pesticides, as it is already done in agriculture.

According to the production data, there were no differences among treatments (Table 3); that is, the presence of aphids did not cause a reduction in production compared to the control; which may have occurred because of the greater presence of the natural enemy (Fig. 2), which helped lowering production losses, even with a greater presence of aphids.

Table 3. Production of beans grown in pots under greenhouse conditions using different insecticides in the control of Aphis craccivora.

\begin{tabular}{lccccc}
\hline \multicolumn{1}{c}{ Treatment } & Pods per plant $^{*}$ & Seeds per pod $^{*}$ & Seeds per treatment & Mass of 100 seeds & Total mass $^{*}$ \\
\hline Neem extract & $7.37 \pm 2.11$ & $3.53 \pm 2.66$ & $248.00 \pm 72.51$ & $24.08 \pm 1.60$ & $59.03 \pm 18.34$ \\
\hline d-limonene & $6.50 \pm 1.12$ & $4.34 \pm 0.36$ & $290.28 \pm 51.06$ & $24.93 \pm 1.47$ & $68.23 \pm 12.76$ \\
\hline Imidacloprid + bifenthrin & $7.64 \pm 1.24$ & $3.74 \pm 0.47$ & $280.00 \pm 63.43$ & $23.99 \pm 1.33$ & $63.12 \pm 15.95$ \\
\hline Control & $5.57 \pm 1.36$ & $4.91 \pm 0.75$ & $218.28 \pm 31.71$ & $22.80 \pm 2.15$ & $50.36 \pm 10.90$ \\
\hline Coefficient of variation & $24.12 \%$ & $38.53 \%$ & $23.67 \%$ & $7.54 \%$ & $26.51 \%$ \\
\hline
\end{tabular}

*Data not significant according to the $\mathrm{F}$ test at $5 \%$ probability. 
Regarding the production parameters, no significant differences were observed (Table 3), which may suggest that, under the conditions tested, the average aphids of around 33.58 individuals per plant (Table 2) was not sufficient to reduce production. Another possibility is that, due to the experiment being conducted in a greenhouse, the smaller production scale concerning the field may have interfered in detecting differences in production.

Mansour et al. (2000) suggested that an infestation greater than 30 aphids per leaf in common beans can result in production losses of up to $2.6 \mathrm{t} \mathrm{ha}^{-1}$. Considering this value, it can be inferred that the population density found in the control treatment was close to that determined by the authors, and, from then on, it can start to cause damage if control measures were not taken. Abdou et al. (2012) suggested that the number of aphids per plant of $V$. faba should be used to assist in the decision of the producer to control the insect. Associating the information provided by the studies present herein and the results of the present study, we could infer the importance to adopt different methods to control $A$. craccivora, including alternative strategies to an integrated pest management plan in order to control the aphid populations below the economic injury level.

Although many aphids are susceptible to chemical insecticides, and they are widely used in the control of $A$. craccivora, they are not always successful in reducing insect populations, which may be related to the fact that the natural enemies of aphids also could be susceptible or resistant to the main insecticides used (Ofuya 1997).

Ofuya (1987) relates the disproportionate growth of $A$. craccivora populations according to the application of some chemical insecticides, such as cypermethrin, due to the elimination of its natural enemies, in addition to the fact that the aphid reproduces more quickly than its natural enemies.

These situations result in population outbreaks of the insect pest, requiring frequent insecticide applications, which result in cases of resistance (Ofuya 1997). Thus, the need to add alternative and effective aphid control methods become evident, such as the use of plant extracts and periodic releases of predators to supplement natural populations.

Considering an Integrated Pest Management scheme of A. craccivora all the tested products could be recommended; however, the influence of the products on coccinellids population should be considered. In this case, further studies should be performed in order to establish an interval after the product application and the release of coccinellids in the field.

\section{Conclusions}

The tested products were considered effective in reducing the populations of $A$. craccivora.

The application technology used allowed an efficient application, which enabled the effectiveness of phytosanitary products.

There was no reduction in bean production in the different treatments.

Natural enemies were affected by the application of the products.

\section{Literature cited}

ABDOU, W. L.; ABDEL-HAKIM, E. A.; SALEM, N. Y., MANSOUR, M. H.; AMR, E. M. 2012. Estimation of economic injury level of Aphis craccivora Koch. (Homoptera: Aphididae) infesting faba bean in new reclaimed area. Archives of Phytopathology and Plant Protection 45 (15): 1764-1772. http://dx.doi.org/10.1080/03235408.2010.505775

AGROFIT. 2020. Sistemas de agrotóxicos fitossanitários. http:// agrofit.agricultura.gov.br/agrofit_cons/principal_agrofit_cons

ALVARENGA, C. B.; ANDALÓ, V.; MACHADO, F. A. O.; ZAMPIROLI, R.; MIEKO, J.; FARIA, L. S. 2018. Hydraulic spray nozzles for entomopathogenic nematode application. Revista Colombiana de Entomologia 44 (2): 206-210. http://dx.doi. org/10.25100/socolen.v44i2.7322

ALVARENGA, C. B.; TEIXEIRA, M. M.; ZOLNIER, S.; CECON, P. R.; SIQUEIRA, D. L.; RODRIGUES, D. E.; SASAKI, R. S.; RINALDI, P. C. N. 2014. Efeito do déficit de pressão de vapor d'água no ar na pulverização hidropneumática em alvos artificiais. Bioscience Journal 30 (1): 182-193. http://www.seer.ufu. br/index.php/biosciencejournal/article/view/17986

CONAB. 2020. Acompanhamento da safra brasileira de grãos. Brasília: safra 2019/20, n. 5, quinto levantamento. https://www. conab.gov.br/info-agro/safras

CUNHA, J. P. A. R.; REIS, E. F.; ASSUNÇÃO, H. H. T.; LANDIM, T. N. 2019. Evaluation of droplet spectra of the spray tip ad 11002 using different techniques. Engenharia Agrícola 39 (4): 476-481. https://doi.org/10.1590/1809-4430-eng.agric. v39n4p476-481/2019

DAS, B. C.; SARKER, P. K.; RAHMAN, M. M. 2008. Aphidicidal activity of some indigenous plant extracts against bean aphid Aphis craccivora Koch (Homoptera: Aphididae). Journal of Pest Science 81: 153-159. https://doi.org/10.1007/s10340-0080200-6

DROPSCAN ${ }^{\circledR}$. Leon Sistemas Digitais. 2019.

GONÇALVES, M. E. DE C.; BLEICHER, E. 2006. Atividade sistêmica de azadiractina e extratos aquosos de sementes de nim sobre o pulgão-preto em feijão-de-corda. Revista Ciência Agronômica 37 (2): 177-181. http://ccarevista.ufc.br/seer/index.php/ ccarevista/article/view/197

IPERTI, G. 1999. Biodiversity of predaceous coccinellidae in relation to bioindication and economic importance. Agriculture, Ecosystems and Environment 74 (1): 323-342. https://doi. org/10.1016/S0167-8809(99)00041-9

KHANI, A.; ASGHARI J. 2012. Insecticide activity of essential oils of Mentha longifolia, Pulicaria gnaphalodes and Achillea wilhelmsii against two stored product pests, the flour beetle, Tribolium castaneum, and the cowpea weevil, Callosobruchus maculatus. Journal of Insect Science 12: 1-11. https://doi. org/10.1673/031.012.7301

MANSOUR, H. M.; AHMED, S.H.; SALEM, N. Y.; RAMADAN, A. R. 2000. Evaluation of the susceptibility of different corn varieties towards aphid Rhopalosiphum maidis (Fitch) infestation. Bulltein of the Entomological Society of Egypt 78: 205-216. http://www.ees.eg.net/pdf/b2000/14.pdf

MORAIS, C. R. de; TRAVENÇOLO, B. A. N.; CARVALHO, S. M., BELETTI, M. E., VIEIRA, S. V. S.; CAMPOS, C. F.; CAMPOS JÚNIOR, E. O. DE; PEREIRA, B. B.; CARVALHO, M. P. N.; REZENDE, A. A. A. DE; SPANÓ, M. A.; VIEIRA, C. U.; BONETTI, A. M. 2018. Ecotoxicological effects of the insecticide fipronil in Brazilian native stingless bees Melipona scutellaris (Apidae: Meliponini). Chemosphere 206: 632-642. https:// doi.org/10.1016/j.chemosphere.2018.04.153

OBOPILE, M. 2006. Economic threshold and injury levels for control of cowpea aphid, Aphis craccivora Linnaeus (Homoptera: Aphididae) on cowpea. African Plant Protection 12: 111-115. https:/hdl.handle.net/10520/EJC87791

OBOPILE, M.; OSITILE, B. 2010. Life table and population parameters of cowpea aphid, Aphis craccivora Koch (Homoptera: 
Aphididae) on five cowpea Vigna unguiculata (L. Walp.) varieties. Journal of Pest Science 83: 9-14. https://doi.org/10.1007/ s10340-009-0262-0

OFUYA, T. I. 1987. A population explosion of Aphis craccivora Koch (Homoptera: Aphididae) in cowpeas protected with cypermethrin. FAO Plant Protection Bulletin 35: 75-77. https://www. cabi.org/ISC/abstract/19881108357

OFUYA, T. I. 1995. Studies on the capability of Cheilomenes lunata (Fabricius) (Coleoptera: Coccinellidae) to prey on the cowpea aphid, Aphis craccivora Koch (Homoptera: Aphididae) in Nigeria. Agriculture, Ecosystem \& Environment 52 (1): 35-38. https://doi.org/10.1016/0167-8809(94)09006-S

OFUYA, T. I. 1997. Control of the cowpea aphid, Aphis craccivora Koch (Homoptera: Aphididae), in cowpea, Vigna unguiculata (L.) Walp. Integrated Pest Management Reviews 2: 199-207. https://link.springer.com/article/10.1023/A:1018461320137

OFUYA, T. I.; OKUKU, I. E. 1994. Insecticidal effect of some plant extracts on the cowpea aphid, Aphis craccivora Koch (Homoptera: Aphididae). Anzeiger für Schädlingskunde 67: 127-129. https://doi.org/10.1007/BF01909033

PERVEZ, A.; AWASTHI, P.; BOZDOĞAN, H. 2019. Biological Control of Aphis craccivora (Koch) with predaceous ladybird, Hippodamia variegata (Goeze). Indian Journal of Ecology 46 (7): 141-144.

RABELO, J. da S.; BLEICHER, E. 2014. Controle de pulgão-preto em feijão-caupi com o uso de sementes de Annonaceae e a bioatividade das sementes em diferentes épocas de armazenamento. Agropecuária Científica no Semiárido 10 (4): 5-8. http://revistas. ufcg.edu.br/acsa/index.php/ACSA/article/view/603

RIBEIRO, A. C.; GUIMARAES, P. T. G.; ALVAREZ, V. V. H. 1999. Recomendação para o uso de corretivos e fertilizantes em Minas Gerais: uso de gesso agrícola. $5^{\circ}$ Aproximação. Viçosa: Comissão de Fertilidade do Solo do Estado de Minas Gerais, p. 67-78.

SANTOS, C. A. B. dos; SILVA, A. P. M. da; SCHER, F. de A.; ROCHA, A. G.; SILVA, J. A. da; MOREIRA, J. O. T. 2011. Atividade inseticida de extratos vegetais contra o pulgão (Aphis craccivora Koch) do feijão caupi (Vigna unguiculata). Cadernos de Agroecologia 6 (2): 1-5. http://revistas.aba-agroecologia.org. br/index.php/cad/article/view/11913

SASAKI, R. S.; TEIXEIRA, M. M.; FERNANDES, H. C.; ZOLNIER, S.; MACIEL, C. F. S.; ALVARENGA, C. B. 2016. Droplets spectrum of air-assisted boom sprayers under different environmental and operational conditions. Revista Brasileira de Engenharia Agrícola e Ambiental 20 (1): 92-96. https://doi. org/10.1590/1807-1929/agriambi.v20n1p92-96

SILVA, F. A. S.; AZEVEDO, C. A. V. 2009. Principal components analysis in the software assistat-statistical attendance. $7^{\text {th }}$ World Congress on Computers in Agriculture Conference Proceedings, 22-24 June, Reno, Nevada 711P0409e. https:// doi:10.13031/2013.29066

SILVA, J. F.; BLEICHER, E.; MARQUES, G. V.; SILVA, V. 2014. Distribuição espacial do pulgão preto em feijão de corda e cálculo do número de amostras. Revista Ciência Agronômica 45 (3): 537-542. https://doi.org/10.1590/S1806-66902014000300014

TORKEY, H. M.; ABOU-YOUSEF, H. M.; ABDEL AZEIZ, A. Z.; HODA, E. A. F. 2009. Insecticidal effect of cucurbitacin e glycoside isolated from Citrullus colocynthis against Aphis craccivora. Australian Journal of Basic and Applied Sciences 3 (40): 40604066. http://www.ajbasweb.com/old/ajbas/2009/4060-4066.pdf

YANIV, Z.; SHABELSKY, E.; SCHAFFERMAN, D. 1999. Colocynth: potential arid land oilseed from an ancient. p. 257-261. In: Janick, J. (Ed.). Progress in new crops and new uses. ASHS Press. Alexandria, VA, USA. 528 p.

\section{Origin and funding}

This study was supported by Universidade Federal de Uberlândia and Programa de Pós-graduação em Agricultura e Informações Geoespaciais.

\section{Author contribution}

Mateus Cardoso de Sousa and Vanesa Andaló: carried out the experiments and wrote the manuscript. Renan Zampiroli, Cleyton Batista de Alvarenga, Lucas Silva de Faria and Welington Adolfo de Brito: carried out the experiments and revised the manuscript. Gleice Aparecida de Assis and Fabio Janoni Carvalho: analyzed the data and performed the interpretation of the results and revised the manuscript.

Conflict of interests: The authors participating in this publication made significant contributions to the manuscript; all authors agree and express that there are no conflicts of interest in this study. 